\title{
Cytogenetic characteristics of seed progeny of old-aged trees of Pinus pallasiana and Picea abies (Pinaceae)
}

\author{
Ivan I. KORSHIKOV ${ }^{1,2}$, Yuliia O. BILONOZHKO ${ }^{*}$ (D), Volodymyr M. HRABOVYI ${ }^{4}$ \\ ${ }^{1}$ Donetsk Botanical Garden of NAS of Ukraine, 50 Marshak Str., Kryvyi Rih 50089, Ukraine \\ ${ }^{2}$ Kryvyi Rih Botanical Garden of NAS of Ukraine, 50 Marshak Str., Kryvyi Rih 50089, Ukraine \\ ${ }^{3}$ Institute of Food Biotechnology and Genomics of NAS of Ukraine, 2-a Osipovskoho Str., Kyiv 04123, Ukraine \\ ${ }^{4}$ Sofiivka National Arboretum of NAS of Ukraine, 12-a Kyivska Str., Uman 20300, Ukraine
}

\begin{abstract}
Information on cytogenetic changes in the seed offspring of old-aged trees is insufficient and inconsistent. In our studies, 150-200-year old trees of Picea abies and Pinus pallasiana were used. We analyzed peculiarities of their karyotype, nucleus-forming region, and nucleolus in the cells of seedlings of $P$. abies and $P$. pallasiana emerged from seeds in natural populations and plantations of introduced plants. As a result, age-dependent cytogenetic disorders were observed, such as the chromosome bridges, lag, premature segregation, and agglutination. Peculiarities with regard to number and structure of secondary chromosome constriction are demonstrated. The identified properties of the cell structure of seeds of old-aged trees of $P$. abies and $P$. pallasiana indicate that more resources are needed to maintain their protein synthesis at a normal level. The increased number of abnormalities indicates a significant impact of accumulated intracellular metabolites and cytopathological phenomena in mother plants on the quality of seed offspring.
\end{abstract}

Keywords: chromosomal aberrations, nuclear and nucleolar characteristics, old-aged trees, Picea abies, Pinus pallasiana

Article history. Submitted 25 September 2020. Revised 07 December 2021. Published 31 December 2021

Citation. Korshikov I.I., Bilonozhko Y.O., Hrabovyi V.M. 2021. Cytogenetic characteristics of seed progeny of oldaged trees of Pinus pallasiana and Picea abies (Pinaceae). Ukrainian Botanical Journal, 78(6): 434-441. https://doi. org/10.15407/ukrbotj78.06.434

*Corresponding author (e-mail: tkacheva_ua@ukr.net)

\section{Introduction}

From the seed germination to aging sub-senile period, the plant physiological state changes, and age-related and organ-forming processes occur simultaneously. Many patterns of age-related changes leading to functional rearrangements, especially the molecular basis of ontogenesis in higher plants, have not yet been elucidated sufficiently. With aging, living organisms have both programmed and stochastic changes in their macromolecular properties, reflected in the finest structures, including the synthesis of nucleic acids and cell proteins. Aging is accompanied by the accumulation of damage, failure in the body systems and other changes leading to the loss of functionality.
Age-related changes occur at different levels of organization of a living organism (molecular, cellular, tissue, and organ). The aging of the whole plant reflects the processes occurring in all its constituent organs and is closely related to the slowdown or cessation of the tissue and organ growth. Plant aging is usually characterized by a decrease in the intensity of photosynthesis, respiration, protein synthesis, RNA synthesis, activity of ion transport, and other physiological processes (Calderwood et al., 2009; Gladyshev, 2016; Anisimova et al., 2018).

In the age-related change process, complexly regulated functional systems are involved; in some cells, the aging processes develop, while in other ones the adaptive shifts occur along with unequal mitotic activity. With age, cell "replicative aging" begins, that is, irreversible inhibition

(C) 2021 I.I. Korshikov, Y.O. Bilonozhko, V.M. Hrabovyi. Published by the M.G. Kholodny Institute of Botany, NAS of Ukraine. This is an open access article under the terms of the Creative Commons Attribution License (http://creativecommons.org/licenses/by/4.0/), which permits use, distribution, and reproduction in any medium, provided the original work is properly cited 
of DNA replication appears. Age-related changes in the DNA structure are reflected on the organisms themselves as well as on their descendants. An increase in the occurrence of genetic pathologies in the progeny is observed in many species of various forms of life (Wojda et al., 2006; Vostrikova, 2007). For this reason, seeds collected from generatively mature trees are used in afforestation process for the cultivation of planting material and they are not harvested from old trees that pass into the sub-senile ontogenetic stage.

Cytogenetically, cell aging is associated with a number of significant cellular changes in tissues, including cell cycle arrest, increased and/or heterogeneous cell size, their higher frequency with different chromosomal aberrations and micronuclei. Classical and molecular cytogenetic studies of dividing and interphase cells in the elderly organisms have shown an increase in the frequency of cytogenetic disorders (Bolognesi et al., 1999; Butorina et al., 2000; Gladishev et al., 2016; Janssens, Veenhoff, 2016; Korshikov et al., 2019). Numerous monitoring cytogenetic studies on plant and animal species have shown that this method is highly effective for assessing the negative impact of both natural and technogenic factors on living organisms (Akinboro et al., 2011; Wang et al., 2014; Pekol et al., 2016; Krysanov et al., 2018). For such studies, conifers and their seed progeny are often used as monitoring objects (Butorina et al., 2008; Kvitko, Muratova, 2010).

The plant reproductive system is one of the first to respond to climate changes. In the seed progeny (seed embryos) of plants exposed to air pollutants (Korshikov et al., 2007), as well as in areas with adverse climatic conditions, the proportion of homozygotes can significantly increase (Korshikov, Mudrik, 2006) The genetic structure of populations can change, as well as an increase in the level of pathologies of mitosis, chromosomal aberrations, the nucleus-nucleolus ratio is shifting (Korshikov et al., 2013).

Old-growth trees are of great interest to humans. Previously, they were considered as a source of raw materials for various types of production. Currently, such plants are designated as objects that need to be protected and comprehensively studied. There is little information on how cytogenetic indicators change in components of plant populations of different ages, and especially in areas with adverse climatic conditions, and they are contradictory (Cherkashina, 2007; Butorina et al., 2008; Mashkina et al., 2012). It is known that the population seed pool is formed primarily by middle-aged generative trees and, to a lesser extent, young and old plants (Isajev et al., 2013).
The purpose of the work is to elucidate the peculiarities of cytogenetic changes in the middle- and old-aged tree seed progeny of Picea abies (L.) H.Karst. and Pinus pallasiana D.Don. in natural populations and introduction plantations.

\section{Materials and Methods}

Currently, old trees are found only in the territories of ancient parks, as well as in places difficult to access for economic and recreational human activities.

For the present research, we used the seeds of oldaged Crimean pine (Pinus pallasiana) and Norway spruce (Picea abies) trees from plantations of the Sofiivka National Arboretum of the National Academy of Sciences of Ukraine (Uman town, Cherkasy Region, Ukraine). The age of the studied plants of $P$. pallasiana was about 130-150 years, and that of trees of $P$. abies was about 180-200 years. In addition, individual plants of $P$. abies had a morphological abnormality called witches' brooms. The seeds from middle-aged trees were collected in natural populations. For $P$. pallasiana, this was the Crimean Mountains (Nikita settlement), the trees aged 80-100 years; for P. abies - Ukrainian Polissia (Rostansk Forestry, Volyn Region), the trees aged 65-75 years. Each sample plot consisted of 30 trees, with at least 200 mitoses analyzed per one tree. In total, about 25000 cells were analyzed.

The analysis of cytogenetic parameters was carried out on temporary preparations of the seedling root meristematic tissues. Seeds were germinated in Petri dishes on wet filter paper in a thermostat at temperatures of $23-25{ }^{\circ} \mathrm{C}$. The first wave of mitoses was analyzed

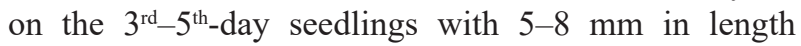
roots. Subsequent mitoses were determined on 1.0-1.5 $\mathrm{mm}$ in length roots. The roots were fixed with acetic alcohol (1:3). To analyze the mitosis pathologies and chromosomal aberrations, the material was stained with $2 \%$ solution of aceto-orcein, and thermal maceration was performed. The identified abnormalities were classified based on the research of Bochkov et al. (1972) and Glińska et al. (2007).

For karyological analysis, the sprouted roots were treated with $1 \%$ aqueous colchicine before fixation. We used $1 \%$ acetohematoxylin solution for staining chromosomes. Metaphase plates with chromosomes in the same plane were photographed under immersion (at a magnification of $100 \times 10$ ). 
For staining of nucleoli, the commonly accepted technique was used (Muratova, 1995). The roots were left in $50 \%$ silver nitrate solution for 3 hours at $60{ }^{\circ} \mathrm{C}$. After staining, the material was washed and squash preparations were made according to conventional cytology protocols (Singh, 2017). For each sample, nucleoli were counted in 1000 interphase nuclei.

Finished preparations were analyzed using a Carl Zeiss Primostar microscope at a magnification of $40 \times 10$, photographed with a Canon Power Shot A620 digital camera. AxioVisionRel 4.7 software was used to determine the chromosome, nuclei and nucleoli size. Quantitative data were presented as mean \pm standard error (SE). Statistical significance was checked using the Student's t-test and was considered significant if the P value was less than 0.05 .

\section{Results}

According to our observations, the middle-aged plant seed progeny of the population of $P$. abies have a rather low level of cytogenetic disorders $(0.32 \pm 0.06 \%)$. Among them, pathologies of mitosis and aberrations associated with the chromosome structure were noted. Of all chromosomal abnormalities, $71.4 \%$ accounted for single bridges, $10.7 \%$ for lagging and $10.7 \%$ for premature segregation, $3.57 \%$ for multiple bridges, and $3.57 \%$ for chromosome agglutination. For the old-aged P. abies tree progeny from the Sofivka arboretum, it was 7.8 times higher and amounted to $2.5 \pm 0.05 \%$. Moreover, the spectrum of anomalies was represented by only two types: chromatid and chromosome bridges $-71.43 \%$, and lagging chromosomes $-28.57 \%$.

All types of chromosomal aberrations are considered as a single phenomenon, as they have a common basis as DNA break. However, various types of chromosomal aberrations arise due to a different number of molecular genetic events, involving dissimilar chromosome morphological regions that vary significantly in their structural and functional features. In addition, individual chromosomes of the same karyotype can significantly differ from each other in the frequency of participation in chromosomal aberrations (Richardson et al., 1998). Some non-mutagenic chemical compounds cause chromosomal aberrations, as well as metabolic poisons that inhibit DNA synthesis and induce double DNA breaks (Nakamura et al., 2021). Only cells carrying chromosomal or chromatid exchanges can be maintained during cytogenetic changes, throughout which there was no loss of genetic material, and if damaged, they can be transmitted to the next generation of cells (Bryant, 1997). In our previous studies, we established the level of cytogenetic disturbances for young trees of $P$. abies (3540 years old, from plantations in the industrial region, Donetsk) (Korshikov et al., 2012). It amounted to 0.40 $\pm 0.06 \%$, which is practically consistent with the results obtained for middle-aged plants of natural populations. In all likelihood, young and middle-aged trees preserve the high efficiency of their DNA repair system, which allows them to produce their seed progeny with significantly fewer genetic disorders. Apparently, the accumulation of unrepaired disorders in an old-aged organism affects genetic characteristics of its progeny.

A similar trend - an increase in the number of pathologies with increasing age-is also observed for other coniferous species. For example, in Pinus sylvestris L. seed embryos, the level of anomalies was almost twice as high in plants from the natural population whose age was 61-67 years than in young plants (35-38 years old) in artificial planting (Pimenov, Sedelnikova, 2006). The same differences in the level of mitosis pathologies have been shown for seed progeny of $P$. sylvestris populations of 70 and 100 years old, and a difference in the level of the mitotic index was noted (Cherkashina, 2007). However, the opposite trend was revealed by Butorina et al. (2008). The highest level of mitosis pathology (7\%) was observed in the seed progeny of $P$. sylvestris 40-50-year-old trees plantings in the aluminum smelter emission area, and the lowest $(0.7 \%)$ - in 120-140-yearold trees from the natural population in an unpolluted area. Probably in this case the aerotechnogenic pollution factors have a greater impact on the cytogenetic process than physiological and age-related features of trees.

Like in many coniferous species, in the chromosomes of seed progeny of $P$. abies and P. pallasiana, a large number of secondary constrictions are observed. In the P. abies karyotype we noted from 3 to 5 pairs with a nucleolar region (in I-III pairs are constant, in IV and VI are not constant), the nucleoli number in the interphase nucleus varied from 2 to 10 . It is generally accepted that permanent secondary constrictions correspond to strong nucleolar organizers, and are not constant and those that appear periodically correspond to the weak and latent ones (Shafikova, Kalashnik, 2000). In the P. pallasiana karyotype, three constants (I-III pairs) and three nonconstants (IV-VI pairs) constrictions were detected. The nucleoli number in the nucleus ranged from 1 to 11 . The mismatch of the chromosome number with the nucleolar organizer and the nucleoli number in the interphase 

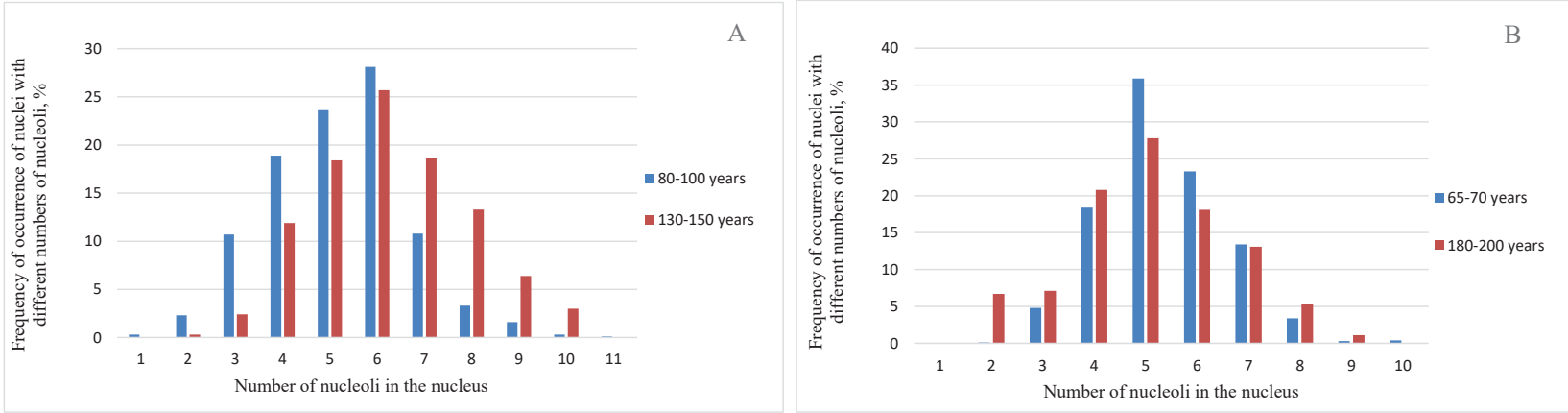

Fig. 1. The nuclei frequency with different nucleoli numbers in interphase seedling cells of different age groups of Pinus pallasiana (A) and Picea abies (B)

nucleus may indicate that not all secondary constrictions in the chromosomes of these species are nucleolar. In addition, it was noted that not only the quantity but also the width of the secondary constriction region varies. This can be explained by the different functional activities of ribosomal genes concentrated in this chromosome region, and is reflected in the nucleoli formation in the nucleus with different morphometric parameters. The nucleoli themselves in the process of functioning also tend to merge (Mosgoeller, 2004; Zharskaya, Zatsepina, 2007).

In our previous studies we observed in the progeny of $P$. pallasiana and $P$. abies the characteristic differences in the level of chromosome nucleolar organizer activity, depending on the growing conditions and the effect of different-quality factors of the technogenic polluted environment (Tkachova et al., 2012; Korshikov et al., 2013). The age of the trees used in these studies was
35 to 45 years. For old-aged trees of these two species, features of the nucleoli functioning in the nucleus have also been established. The average number of nucleoli in the interphase nucleus in middle-aged $P$. pallasiana trees was $5.2 \pm 0.05$. A significant increase in this indicator $(6.3 \pm 0.05)$ was revealed in the seedling cells of old-aged plant seeds. At the same time, $76 \%$ of all interphase cells contained nuclei with 5-8 nucleoli, while in middle-aged $70.6 \%$ of cells had $4-6$ nucleoli (Fig. 1).

We revealed some differences in the size of individual nucleoli in the nucleus (Table 1). In the interphase cells of one seedling, nucleoli of similar size and those of significantly variable size were observed.

When comparing the size of nuclear structures for seed progeny of old plants of $P$. pallasiana, a decrease in the nucleus area and an increase in the nucleoli area were revealed (Table 2).

Table 1. Morphological polymorphism of the nucleolus in the seedling root meristem cells of trees of Pinus pallasiana and Picea abies of different age

\begin{tabular}{|c|c|c|c|c|c|}
\hline \multirow{2}{*}{\multicolumn{2}{|c|}{ Plant species and age }} & \multicolumn{3}{|c|}{ Nucleolus area, $\mu \mathrm{m}^{2}$} & \multirow{3}{*}{$\begin{array}{c}\text { CV (\%) } \\
60.52 \\
\end{array}$} \\
\hline & & \multirow{2}{*}{$\begin{array}{c}\min \\
0.88 \pm 0.02 \\
\end{array}$} & \multirow{2}{*}{$\begin{array}{c}\max \\
25.64 \pm 1.95\end{array}$} & \multirow{2}{*}{$\begin{array}{c}\text { mean } \\
6.47 \pm 0.26 \\
\end{array}$} & \\
\hline Pinu oullocin & $80-100$ & & & & \\
\hline Thus parlasiana & $130-150$ & $0.96 \pm 0.03 * *$ & $34.82 \pm 2.13 * * *$ & $6.07 \pm 0.22$ & 64.48 \\
\hline \multirow{2}{*}{\begin{tabular}{|l|} 
Picea \\
abies
\end{tabular}} & $65-70$ & $0.74 \pm 0.03$ & $27.28 \pm 2.08$ & $4.10 \pm 0.22$ & 76.20 \\
\hline & $180-200$ & $0.56 \pm 0.03 * * *$ & $45.32 \pm 3.05 * * *$ & $4.31 \pm 0.30$ & 84.08 \\
\hline
\end{tabular}

Differences are significant at $*-p \leq 0.05 ; * *-p \leq 0.01 ; * * *-p \leq 0.001$

Table 2. The nucleus and nucleoli area, the nucleus-nucleolus ratio in the seedling cells of Pinus pallasiana and Picea abies

\begin{tabular}{|c|c|c|c|c|c|c|c|}
\hline \multirow{2}{*}{\multicolumn{2}{|c|}{ Plant species and age }} & \multicolumn{2}{|c|}{ The average area 1 nucleus, $\mu \mathrm{m}^{2}$} & \multicolumn{2}{|c|}{$\begin{array}{l}\text { The average area of nucleoli in } \\
\text { nucleus } 1, \mu \mathrm{m}^{2}\end{array}$} & \multicolumn{2}{|c|}{$\begin{array}{c}\text { Nucleus-nucleolus } \\
\text { ratio }\end{array}$} \\
\hline & & $\mathrm{x} \pm \mathrm{SE}$ & $\mathrm{CV}(\%)$ & $\mathrm{x} \pm \mathrm{SE}$ & $\mathrm{CV}(\%)$ & $\mathrm{x} \pm \mathrm{SE}$ & $\mathrm{CV}(\%)$ \\
\hline \multirow{2}{*}{ Pinus pallasiana } & $80-100$ & $192.6 \pm 10.2$ & 37.5 & $28.6 \pm 1.4$ & 33.7 & $7.24 \pm 0.4$ & 42.1 \\
\hline & $130-150$ & $141.5 \pm 5.2 * * *$ & 26.3 & $30.3 \pm 0.7$ & 16.7 & $4.27 \pm 0.6^{* * *}$ & 23.3 \\
\hline \multirow{2}{*}{$\begin{array}{l}\text { Picea } \\
\text { abies }\end{array}$} & $65-70$ & $199.52 \pm 13.61$ & 15.3 & $22.08 \pm 5.28$ & 23.2 & $12.72 \pm 0.73$ & 14.1 \\
\hline & $180-200$ & $101.61 \pm 4.35^{* * *}$ & 32.6 & $19.07 \pm 1.38$ & 52.5 & $6.77 \pm 0.32 * * *$ & 27.7 \\
\hline
\end{tabular}

Differences are significant at* $-p \leq 0.05 ; * * *-p \leq 0.001$. SE - standard error 
Variations in the size of the nucleus in the seeds of $P$. pallasiana is a result of nuclear-cytoplasmic interactions, and a decrease in the nucleus volume is obviously associated with changes in the non-histone protein-nuclear matrix (Olson et al., 2002; Hein et al., 2012). Since the studied plants of $P$. pallasiana are not damaged, in general, nucleus morphometric changes in their seed cells can be considered adaptive. However, programmatic changes at the DNA level are unlikely to occur in seed cells, although deviations in the expression of individual genes are not excluded.

Apparently, changes in the structures responsible for the synthetic process activity occur in the seed progeny cells of $P$. abies and P. pallasiana of different ages.

\section{Discussion}

It is well known that aging process develops gradually, and young and dying cells and organs in an adult plant, due to the activity of the meristems, function simultaneously. On the plant level, the growth continues, but its rate gradually slows down. An increase in pathological changes in plant seeds with an increase in their age can be explained by disorders in metabolic processes, and as a result of this by the action of intracellular metabolites. Moreover, with aging, the error accumulation in the DNA structure is observed in the organism cells, which in turn influences the physiological processes throughout the whole organism (Wojda et al., 2006; Vostrikova, 2007).

Aging is the result of a genetically programmed process combined with the influence of environmental factors (both exogenous and endogenous ones) (Wojda et al., 2006). Both classical and molecular cytogenetic studies suggest that cell aging is associated with decreased genome stability (Bolognesi et al., 1999).

Every living cell has a proteome consisting of thousands of different proteins. In order for the cells to work well and smoothly, they need to maintain proteostasis, a balance of the processes of protein synthesis and breakdown. With age, the proteome reflects all the errors that accumulate on the path to the realization of genetic information. "Spoiled" proteins can be collected in insoluble aggregates and interfere with normal cell functioning. An aging organism suppresses translation so that cells are not overloaded with new proteins to save energy (Anisimova et al., 2018).

It is known that specific nucleolus proteins also take part in the regulation of the cell cycle, aging, and apoptosis (Olson et al., 2002; Zharskaya, Zatsepina,
2007; Lempiainen, Shore, 2009; Severine et al., 2010; Hein et al., 2012). These functions are performed by the nucleolus mainly at the interphase stage and are blocked during mitotic cell division when the nucleolus decays. The nucleoli formation and their number in the nucleus depend on the nucleolar region functional activity of the chromosomes (NOR), and is associated with physiological and molecular genetic processes in the cell (Schwazzacher, Wachtler, 1993; Severine et al., 2010).

Changes in the size of the nucleolar nucleoli index are considered an objective, sensitive and highly informative criterion for assessing the protein biosynthesis intensity in different species (Arkhipchuk, 1995; Khaidarova, Kalashnik, 1999; Stepinski, 2014). For old plants of P. pallasiana, the nucleus-nucleolus ratio was $4.27 \pm 0.6$, while for plants aged $80-100$ years this ratio was $7.24 \pm 0.4$. A decrease in the nucleus-nucleolus ratio indicates an increase in synthetic processes in the cell. However, taking into account the characteristics of the studied plants, it would be more reasonable to talk about maintaining the protein biosynthesis processes at a level sufficient to maintain the normal life of the progeny.

Similar trends were revealed in the quantitative characteristics of the seed progeny of old plants of P. abies (see Tables 1 and 2). In addition to reducing the nucleus size in the germinated seed cell of these plants, a decrease in the nucleoli area and, accordingly, the nucleus-nucleolus ratio was also established. Such results, as in the case of $P$. pallasiana, may indicate the need for the body to spend more resources to maintain its homeostasis and proteostasis. We noted earlier a similar phenomenon (a decrease in the nucleus size) in P. abies plants that had a weakened vital potential (Tkachova, Korshikov, 2012).

Life expectancy and, consequently, the death of each plant are genetically determined. The age of trees often correlates with the level of their genetic polymorphism (López-Almansa, Gil, 2003; Zalapa et al., 2010). When analyzing allelic and genotypic heterogeneity for samples of $P$. pallasiana of different age groups (14-16, 70-80 and 120-150 years) in populations from the Crimean Mountains, some differences in the genetic structure were detected (Korshikov, 2010). Of the three analyzed samples of $P$. pallasiana, the smallest proportion of polymorphic loci and the average number of alleles per locus were found in old-aged plants. These trees are characterized by a markedly lower level of observed and expected heterozygosity in comparison with young plants. 
An important index of the population genetic status, as it is known, is the level of heterozygosity. One of the heterozygosity population indices is germinal death: a fairly variable reproductive trait that indicates the percentage of seeds with the absent, underdeveloped, or lost (aborted) embryo due to infertility. Indeed, in wind-pollinated plants, the embryos are often aborted after self-pollination due to the transition of loci with heterozygosity ensured by natural selection to the homozygous state, which may be accompanied by an increase in the expression of harmful recessive, lethal or sublethal genes (López-Almansa, Gil, 2003).

High heterozygosity for one of the four studied loci was found in two populations of $P$. abies when comparing adult trees - embryos - annual seedlings - 8-10-year-olds and 30-40-year-old plants (Konnert, 1991). While changes in the genetic structure of the population of Picea glauca (Moench) Voss, depending on the plant age, were not detected (Tremblay, Simon, 1989), we previously found a significantly lower level of heterozygosity in old-growth trees compared to young trees in an isolated population of Pinus fominii subsp. cretacea (Kalen.) L.V.Orlova in Donetsk Region (Korshikov, Mudrik, 2006). At the same time, when comparing the genetic variation of 250-yearold trees of the Polish larch population (Larix polonica Racib.) and its daughter generation, the average observed heterozygosity was practically the same (Lewandowski et al., 1991). An increased level of heterozygosity was established for a 300-400-year-old stand of P. sylvestris in comparison with a group of plants 80-100-yearold. The higher heterozygosity of an older age plants is explained by the natural selection action, which acts as a regulator that inhibits the process of inbreeding and genetic degradation of a species (Tigerstedt et al., 1982). Obviously, age-related changes in the population genetic structure will also be reflected in the cytogenetic characteristics of their seed progeny.

Thus, in seed embryos of the old plants of P. pallasiana and $P$. abies, changes in a number of cytogenetic indices were noted. They are associated with an increase in the number of pathologies, a decrease in the nucleusnucleolus ratio and the size of the nucleoli. Older organisms need to spend more of their body resources to maintain protein synthesis at the level necessary for their normal life. An increase in the number of pathologies in the seed offspring indicates a significant effect of accumulated intracellular metabolites, as well as cytopathological phenomena in mother plants on the quality of their seed offspring.

\section{References}

Akinboro A., Mohammed K., Rathnasamy S., Muniandy V.R. 2011. Genotoxicity assessment of water samples from the Sungai Dua River in Pulau Pinang, Malaysia, using the Allium cepa test. Tropical Life Sciences Research, 22 (2): 23-35.

Anisimova A.S., Alexandrov A.I., Makarova N.E., Gladyshev V.N., Dmitriev S.E. 2018. Protein synthesis and quality control in aging. Aging, 10: 4269-4288. https://doi. org/10.18632/aging.101721

Arkhipchuk V.V. 1995. The use of the nucleolar characteristics in biotesting. Cytology and Genetics, 29(3): 6-12. [Архипчук В.В. 1995. Использование ядрышковых характеристик в биотестировании. Цитология $u$ генетика, 29(3): 6-12].

Bochkov N.P., Demin N.V., Luchnik L.V. 1972. Classification and methods of registering of chromosome aberrations in somatic cells. Genetics, 8: 133-142. [Бочков Н.П., Демин Н.В., Лучник Л.В. 1972. Классификация и методы учета хромосомных аберраций в соматических клетках. Генетика, 8: 133-142].

Bolognesi C., Lando C., Forni A. 1999. Chromosomal damage and ageing: effect on micronuclei frequency in peripheral blood lymphocytes. Ageing, 28: 393-397.

Bryant P.E. 1997. DNA damage, repair and chromosomal damage. International Journal of Radiation Biology, 71: 675-680. https://doi.org/10.1080/095530097143680

Butorina A.K., Ermoloeva V.V., Cherkashina O.N. 2008. Prospects for the use of cytogenetic analysis in forestry on the example of assessing the state of island forests in the Voronezh Region. Advances in Modern Biology, 128: 400408. [Буторина А.К., Ермолоева В.В., Черкашина О.Н. 2008. Перспективы использования цитогенетического анализа в лесоводстве на примере оценки состояния островных боров Воронежской области. Усnехи современной биологии, 128(4): 400-408].

Butorina A.K., Kalayev V.N., Karpova S.S. 2000. Influence of gender and age of children on the frequency of micronuclei occurrence in buccal epithelium of the oral cavity. Proceedings of Voronezh State University. Series: Chemistry. Biology. Pharmacy, 6: 143-145. [Буторина А.К., Калаев В.Н., Карпова С.С. 2000. Влияние пола и возраста детей на частоту встречаемости микроядер в буккальном эпителии ротовой полости. Вестник Воронежского государственного университета. Серия: Химия. Биология. Фармаичи, 6: 143-145].

Calderwood S.K., Murshid A., Prince T. 2009. The shock of aging: molecular chaperones and the heat shock response in longevity and aging - a mini review. Gerontology, 55: 550-558. https://doi.org/10.1159/000225957

Cherkashina O.N. 2007. Cytogenetic monitoring of common pine plantings under the conditions of the Khrenovsky and Usman pine forests: Cand. Sci. Diss. Abstract. Voronezh, Voronezh State University, 22 pp. [Черкашина О.Н. 2007. Цитогенетический мониторинг насаждений соснь обыкновенной в условиях Хреновского и Усманского боров: автореф. дис. ... канд. биол. наук: спец. 03.00.05 "Ботаніка". Воронеж: Воронежский государственный университет, 22 с.]. 
Gladyshev V.N. 2016. Aging: progressive decline in fitness due to the rising deleteriome adjusted by genetic, environmental, and stochastic processes. Aging Cell, 15: 594-602. https://doi.org/10.1111/acel.12480

Glińska S., Bartczaka M., Oleksiaka S. 2007. Effects of anthocyanin-rich extract from red cabbage leaves on meristematic cells of Allium cepa L. roots treated with heavy metals. Ecotoxicology and Environmental Safety, 68: 343-350. https://doi.org/10.1016/j.ecoenv.2007.02.004

Hein N., Sanij E., Quin J. 2012. The nucleolus and ribosomal genes in aging and senescence. Invited book chapter Senescence Intech Open access Publisher, pp. 171-208. Available at: https://www.intechopen.com/chapters/30030. https://doi.org/10.5772/34581

Isajev V., Lavadinović V., Lučić A., Rakonjac L. 2013. Serbian spruce (Picea omorica (Panc.) Purkyne) variability in the artificial populations in Serbia. Ekológia (Bratislava), 32: 277-282. https://doi.org/10.2478/eko-2013-0024

Janssens G.E., Veenhoff L.M. 2016. The natural variation in lifespans of single yeast cells is related to variation in cell size, ribosomal protein, and division time. PLoS One, 11: e0167394. https://doi.org/10.1371/journal.pone.0167394

Khaidarova T.G., Kalashnik N.A. 1999. Chromosome nucleolar organizers as adaptive elements of conifers. Cytology, 41(12): 1086-1089. [Хайдарова Т.Г., Калашник Н.А. 1999. Ядрышковые организаторы хромосом как адаптивные элементы хвойных видов. Цитология. 41(12): 1086-1089].

Konnert M. 1991. Die Fichte (Picea abies (L.) Karst.) in Schwartzwald: genetische Variation und Korrelationen. Fortwissenschaftliches Centralblatt vereinigt mit Tharandter forstliches Jahrbuch [European Journal of Forest Research], 110: 84-94. https://doi.org/10.1007/ BF02741242

Korshikov I.I. 2010. Population genetics and reproductive biology of Crimean pine. Donetsk, 244 pр. [Коршиков И.И. 2010. Популяционная генетика и репродуктивная биология сосны крыммкой. Донецк, 244 с.].

Korshikov I., Belonozhko Yu., Lapteva H. 2019. Cytogenetic abnormalities in seed progenies of Pinus pallasiana D.Don stands from technogenic polluted lands in the steppe of Ukraine. Ekológia (Bratislava), 38: 117-125. https://doi. org/10.2478/eko-2019-0009

Korshikov I.I., Mudrik E.A. 2006. Age-related dynamics of genetic variation in an isolated population of Cretaceous pine (Pinus sylvestris var. cretacea Kalenicz. ex Kom.) in the Donbass. Genetics, 42: 659-666. [Коршиков И.И., Мудрик Е.А. 2006. Возрастная динамика генетической изменчивости в изолированной популяции сосны меловой (Pinus sylvestris var. cretacea Kalenicz. ex Kom.) в Донбассе. Генетика, 42(5): 659-666].

Korshikov I.I., Tkachova Y.A., Privalikhin S.N. 2012. Cytogenetic abnormalities in Norway spruce (Picea abies (L.) Karst.) seedlings from natural populations and an introduction plantation. Cytology and Genetics, 46: 280-284. https://doi.org/10.3103/S0095452712050064

Korshikov I.I., Lapteva Ye.V., Tkachova Yu.A. 2013. Variation in quantitative-dimensional characteristics of nucleoli and nuclei in seed cells of Pinus pallasiana
D.Don (protected and human-disturbed areas in the steppe zone of Ukraine). Ukrainian Botanical Journal, 70(6): 805-812. [Коршиков I.I., Лаптєва О.В., Ткачова Ю.О. 2013. Мінливість кількісно-розмірних характеристик ядерець та ядер у клітинах насіння Pinus pallasiana D. Don (заповідні й антропогенно змінені території степової зони україни). Украӥнський ботанічний журнал, 70(6): 805-812].

Korshikov I.I., Pirko N.N., Mudrik E.A., Pirko Y.V. 2007. Maintenance of genetic structure in progenies of marginal mountainous and steppe populations of three species of Pinaceae Lindl. family in Ukraine. Silvae Genetica, 56: $1-10$.

Krysanov E.Yu., Ordzhonikidze K.G., Simanovsky S.A. 2018. Cytogenetic indicator in estimation of environmental state. Russian Journal of Developmental Biology, 49: 41-47. https://doi.org/10.1134/S1062360418010034

Kvitko O.V., Muratova E.N. 2010. Karyological characteristics of Siberian fir (Abies sibirica Ledeb.) in Central Siberia. Cell Tissue Biology, 4: 215-222. https://doi.org/10.1134/ $\underline{\mathrm{S} 1990519 X 10020124}$

Lempiainen H., Shore D. 2009. Growth control and ribosome biogenesis. Current Opinion in Cell Biology, 21: 855-863.

Lewandowski A., Burczyk J., Meinartowicz L. 1991. Genetic structure and the mating system in an old stand of Polish larch. Silvae Genetica, 40: 75-79.

López-Almansa J.C., Gil L. 2003. Empty samara and parthenocarpy in Ulmus minor s. 1. Silvae Genetica, 52: 241-243.

Mashkina O.S., Tikhonova I.V., Muratova E.N., Muray L.S. 2012. Cytogenetic features of seed progeny of dwarf pines in the south of Eastern Siberia. Khvoynyye boreal'noy zony, 30(1-2): 127-135. [Машкина,О.С., Тихонова И.В., Муратова Е.Н., Мурая Л.С. 2012. Цитогенетические особенности семенного потомства карликовых сосен на юге Восточной Сибири. Хвойные бореальной зоны, 30(1-2): 127-135].

Mosgoeller W. 2004. Nucleolar ultrastructure in vertebrate. In: The Nucleolus. New York: Kluwer Acad., pp. 10-20.

Muratova E.N. 1995. Nucleolus staining techniques for karyological analysis of conifers. Botanicheskiy Zhurnal, 80: 82-86. [Муратова Е.Н. 1995. Методики окрашивания ядрышек для кариологического анализа хвойных. Ботанический журнал, 80(2): 82-86].

Nakamura K., Ishii Y., Takasu S., Nohmi T., Shibutani M., Ogawa K. 2021. Chromosome aberrations induced by the non-mutagenic carcinogen acetamide involve in rat hepatocarcinogenesis through micronucleus formation in hepatocytes. Archives of Toxicology, 95(8): 2851-2865. https://doi.org/10.1007/s00204-021-03099-9.

Olson M.O., Hingorani K., Szebeni A. 2002. Conventional and nonconventional roles of the nucleolus. International Review of Cytology, 219: 199-266. https://doi.org/10.1016/ s0074-7696(02)19014-0

Pekol S., Baloğlu M.C., Altunoğlu Ya.C. 2016. Evaluation of genotoxic and cytologic effects of environmental stress in wheat species with different ploidy levels. Turkish Journal of Biology, 40: 580-588. 
Pimenov A.V., Sedelnikova T.S. 2006. Anomalies of mitosis in seedlings of Pinus sylvestris (Pinaceae) in the eutrophic swamp. Botanicheskiy Zhurnal, 91: 1537-1544. [Пименов А.В., Седельникова Т.С. 2006. Аномалии митоза в проростках Pinus sylvestris (Pinaceae) на евтрофном болоте. Ботанический журнал, 91(10): 1537-1544].

Richardson C., Moynahan M.E., Jasin M. 1998. Doublestrand break repair by interchromosomal recombinetion: suppression of chromosomal translocations. Genes \& Development, 15: 3831-3842.

Schwazzacher H.G., Wachtler F. 1993. The nucleolus. Anatomy and Embryology, 188: 515-536.

Severine B., Westman B.J., Saskia H. 2010. The nucleolus under stress. Molecular Cell, 40: 216-227. https://doi. org/10.1016/j.molcel.2010.09.024

Shafikova L.M., Kalashnik N.A. 2000. Characteristics of the karyotype of Scots pine in industrial pollution. Lesovedeniye, 2: 30-36. [Шафикова, Л.М., Калашник, H.A. 2000. Характеристика кариотипа сосны обыкновенной при промышленном загрязнении. Лесоведение, 2: 30-36].

Singh R.J. 2017. Practical Manual on Plant Cytogenetics. Boca Raton, FL: CRC Press, 320 pp. https://doi. org/10.4324/9781351228268

Stepinski D. 2014 Functional ultrastructure of the plant nucleolus. Protoplasma, 251: 1285-1306. https://doi. org/10.1007/s00709-014-0648-6

Tigerstedt P.M.A., Rudin D., Niemela T., Tammisola J. 1982. Competition and neighbouring effect in a naturally regeneration populations of Scots pine. Silva Fennica, 16: 122-129.

Tkachova Yu.O., Korshikov I.I. 2012. Polymorphism of nucleus-nucleolus parameters of Picea abies (L.) Karst (Pinaceae) seed progeny in the natural populations and in the introduction planting. Ukrainian Botanical
Journal, 69(6): 919-925. [Ткачова Ю.О., Коршиков I.I. 2012. Поліморфізм ядерно-ядерцевих параметрів насіннєвого потомства Picea abies (L.) Karst. (Pinaceae) у природних популяціях та інтродукційному насадженні. Украӥнський ботанічний журнал, 69(6): 919-925].

Tremblay M., Simon J.P. 1989. Genetic structure of marginal populations of white spruce (Picea glauca) at its northern limit of distribution in Nouveau-Québec. Canadian Journal of Forest Research, 19: 1371-1379.

Vostrikova T.V. 2007. Instability of cytogenetic indicators and instability of the genome in Betula pendula. Russian Journal of Ecology, 2: 88-92. [Вострикова Т.В. 2007. Нестабильность цитогенетических показателей и нестабильность генома у березы повислой. Экология, 2: 88-92].

Wang Q.L., Zhang L.T., Zou J.H. 2014. Effects of cadmium on root growth, cell division and micronuclei formation in root tip cells of Allium cepa var. agrogarum L. Fyton, 83: 291-298.

Wojda A., Ziętkiewicz E., Mossakowska M., Pawłowski W., Skrzypczak K., Witt M. 2006. Correlation between the level of cytogenetic aberrations in cultured human lymphocytes and the age and gender of donors. Journal of Gerontology: Series A, 61: 763-772. https://doi. org/10.1093/gerona/61.8.763

Zalapa J.E., Brunet J., Guries R.P. 2010. The extent of hybridization and its impact on the genetic diversity and population structure of an invasive tree, Ulmus pumila (Ulmaceae). Evolutionary Applications, 3: 157-168. https://doi.org/10.1111/j.1752-4571.2009.00106.x

Zharskaya O.O., Zatsepina O.V. 2007. The dynamics and mechanisms of nucleolar reorganization during mitosis. Cell and Tissue Biology, 1: 277-292. https://doi. $\underline{\operatorname{org} / 10.1134 / \mathrm{S} 1990519 \times 07040013}$

Рекомендує до друку Є.Л. Кордюм

Коршиков І.І., Білоножко Ю.О., Грабовий В.М. 2021. Цитогенетичні характеристики насінного потомства старовікових дерев Pinus pallasiana та Picea abies (Pinaceae). Украйнський ботанічний журнал, 78(6): 434-441 [In English].

Донецький ботанічний сад Національної академії наук України, вул. Маршака 50, Кривий Ріг 50089, Україна; Криворізький ботанічний сад НАН України, вул. Маршака 50, Кривий Ріг 50089, Україна: I.I. Коршиков. ДУ "Інститут харчової біотехнології та геноміки НАН України", вул. Осиповського 2-а, Київ 04123, Україна: Ю.О. Білоножко. Національний дендрологічний парк "Софіївка" НАН України, вул. Київська 12-а, Умань 20300 , Україна: В.М. Грабовий.

Реферат. Відомостей про цитогенетичні зміни, які відбуваються в насінному потомстві середньо- і старовікових дерев вкрай мало і вони носять суперечливий характер. У дослідженні використовували дерева Picea abies i Pinus pallasiana віком 150-200 років. У клітинах проростків насінин P. abies та P. pallasiana 3 природних популяцій та інтродуційних насаджень проаналізовані особливості каріотипу, ядерцеутворюючого регіону та ядерця; виявлені цитогенетичні порушення, пов'язані із віком материнської рослини. У спектрі патологій спостерігались мости, відставання та забігання хромосом, а також аглютинація. Показано особливості в кількості та структурі вторинної перетяжки хромосом. Виявлені властивості клітинної будови насінин старовікових рослин $P$. abies та P. pallasiana вказують на необхідність витрачати більшу кількість ресурсів організму для підтримки синтезу білків на рівні, необхідному для нормальної життєдіяльності. Збільшення кількості патологій свідчить про значний вплив накопичених внутрішньоклітинних метаболітів та цітопатологічних явищ у материнських рослин на якість насіннєвого потомства.

Ключові слова: особливості ядра та ядерця, старовікові дерева, хромосомні порушення, Picea abies, Pinus pallasiana 